\title{
Stratification of Khartoum urban area by the risk of malaria transmission
}

E.M. Malik, ${ }^{1}$ E.S. Ahmed, ${ }^{2}$ S.M. Elkhalifa, ${ }^{3}$ M.A. Hussein ${ }^{4}$ and A.M.N. Sulieman ${ }^{5}$

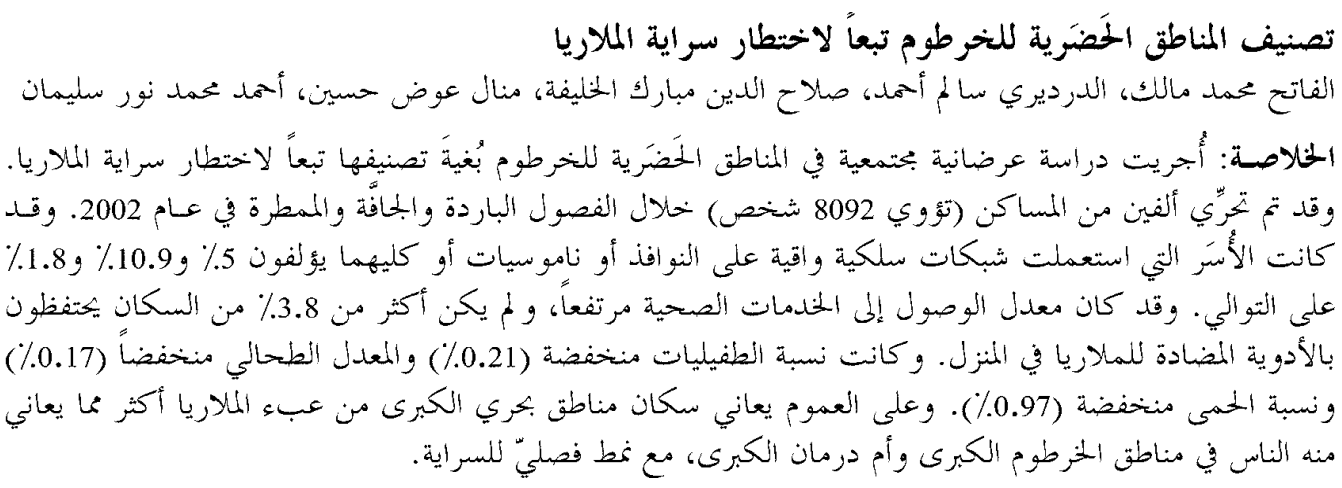

ABSTRACT A cross-sectional community-based study was carried out in Khartoum urban area aimed at stratifying the area by risk of malaria transmission. Two thousand households (8092 individuals) were surveyed during the cold, dry and rainy seasons of 2002. Households with screened windows, using bednets or both were $5.0 \%(95 \% \mathrm{Cl}: 4.1-6.0), 10.9 \%(95 \% \mathrm{Cl}: 9.5-12.3)$ and $1.8 \%(95 \% \mathrm{Cl}: 1.2-2.5)$ respectively. Access to health services was high. Only $3.8 \%(95 \% \mathrm{Cl}: 2.9-4.7)$ of households kept antimalarial drugs at home. The parasite rate, spleen rate and fever rate were very low $(0.21 \%, 0.17 \%$ and $0.97 \%$ respectively). Overall, people in Greater Bahry suffer a greater burden of malaria than those in Greater Khartoum or Greater Omdurman, with a seasonal pattern of transmission.

Stratification de la zone urbaine de Khartoum selon le risque de transmission du paludisme RESUME Une étude communautaire transversale a été réalisée dans la zone urbaine de Khartoum en vue de stratifier la zone selon le risque de transmission du paludisme. Deux mille foyers (8092 individus) ont fait l'objet d'un sondage pendant les saisons froide, sèche et pluvieuse de 2002. La proportion de foyers ayant des fenêtres grillagées, utilisant des moustiquaires de lit, ou les deux était de 5,0 \% (IC $95 \%$ : 4,1-6,0), 10,9\% (IC 95\%: 9,5-12,3) et 1,8\% (IC 95\%:1,2-2,5) respectivement. Le niveau d'accès aux services de santé était élevé. Seulement 3,8 \% (IC $95 \%: 2,9-4,7)$ des foyers conservaient des médicaments antipaludiques à la maison. L'indice plasmodique, l'indice splénique et le taux de fièvre étaient très bas $(0,21 \%$, $0,17 \%$ et $0,97 \%$ respectivement). Globalement, les habitants du Grand Bahri étaient plus touchés par le paludisme que ceux du Grand Khartoum ou du Grand Omdurman, avec une transmission saisonnière.

${ }^{1}$ National Malaria, Schistosomiasis and Lieshmaniasis Control Programme; ${ }^{3}$ Khartoum Malaria Free Initiative; ${ }^{4}$ National Malaria Control Programme, Federal Ministry of Health, Khartoum State, Sudan. ${ }^{2}$ University of Juba, Juba, Sudan.

${ }^{5}$ Surveillance Department, National Malaria Control Programme, Federal Ministry of Health, Khartoum, Sudan.

المجلة الصحية لشرق المتوسط، منظمة الصحة العالمية، المجلد التاسع، العدد ؟، ب... 


\section{Introduction}

Malaria is a leading cause of morbidity and mortality in Sudan, accounting for $50 \%$ of the total reported cases and $70 \%$ of total deaths in the Eastern Mediterranean Region of the World Health Organization [1]. The annual estimated number of cases in Sudan is 7.5 million, with 35000 deaths, representing $20-40 \%$ of the total outpatient attendance and around $30-40 \%$ of hospital admissions. Plasmodium falciparum is the predominant causative organism and the principal malaria vectors are Anopheles arabiensis, An. gambiae and An. funestus. Malaria in Sudan can be stratified to 5 operational bands: riverine (desert-fringe), seasonal, urban, irrigated areas and high perineal transmission malaria. The endemicity level in the first 4 bands is hypoendemic to mesoendemic and in the last is hyperendemic to holoendemic (Federal Ministry of Health, unpublished data, 2002).

Malaria in the study area, Khartoum Urban Area, constitutes a public health problem leading to 310181 cases and 559 deaths each year on average. P. falciparum is resposible for $>85 \%$ of cases but other species have recently been found in increasing numbers $(P$. vivax $8.2 \%$, $P$. ovale $6.2 \%$ ) [2]. An. arabiensis is recognized to be the sole vector.

Malaria transmission is known to be focal in nature; this is attributed to both the parasite and the vector $[3,4]$. Stratification aimed at identifying high and low risk zones needs to be developed in order to conduct efficient, cost-effective interventions for each zone separately.

The main objective of this study was to stratify Khartoum urban area by risk of malaria transmission. The specific objectives were the development of a base-line risk map to assist evidence-based planning and implementation of malaria control measures and the estimation of the prevalence of malaria in the area, taking into consideration various socioepidemiological factors.

\section{Methods}

\section{Study setting and population}

Khartoum state is one of the 26 states in Sudan and has a population of about 5 million, [5]. The area lies within the poor savannah region, characterized by a short rainy season (July to September), a short winter (January to March) and a relatively longer summer. The total area of the state is over $28000 \mathrm{~km}^{2}$. It is divided by the Blue Nile, White Nile and the River Nile into 3 greater areas. The various administrative divisions of the state differ in topography, agriculture and socioeconomic activities; great diversity is also seen within each area. The soil varies from sandy to muddy, and in some areas is rocky.

Malaria in the state is a man-made malaria as identified by the routine inspection of potential breeding sites during past years. Agricultural activities are the main source of mosquito breeding sites in rural areas but broken pipes, small farms at the riverbanks, water tanks in buildings under construction, and indoor sites (inside houses and public and private institutions) are the main breeding sites in urban areas. Broken pipes, small farms and indoor breeding sites $(32.6 \%, 25.4 \%$ and $23.7 \%$ of all breeding sites respectively during 2002) keep malaria transmission going all the year round in the urban part of the state (Khartoum State Ministry of Health, unpublished data, 2001).

Khartoum urban area, where the study was conducted, has $80 \%$ of the population of Khartoum state (4 million inhabitants) and lies on an area of $1000 \mathrm{~km}^{2}$. The major-

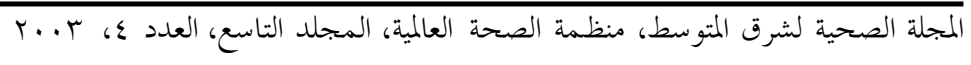


ity of the population are public or private employees. People from different tribes and different areas have settled in the area, some of them displaced from holoendemic/ hyperendemic zones. The area is divided into 3 greater areas: Khartoum, Bahry and Omdurman, each subdivided into zones.

\section{Study design}

This was a cross-sectional communitybased study in which 3 surveys were conducted during the last week of each of the following months: January, May and September 2002.

\section{Sample size and sampling technique}

The study population comprised all the administrative zones in the 3 urban areas. Each zone was divided into 3 divisions, one covered in each survey period. In each division the study unit was the household and its members and the surroundings. Based on population proportions, a total of 2000 households (Khartoum 621, Omdurman 574, Bahry 805) totalling 8092 individuals (Khartoum 2649, Omdurman 2201, Bahry 3242) were surveyed during the study period. The houses in each division were selected systematically. The first house was selected at random and successive households were selected in the same direction. All individuals in the selected household, irrespective of age or gender, were surveyed after obtaining verbal consent. The May survey started with the house next to the last one surveyed in January and the same process followed in the September survey. We surveyed 637 households in January, 649 in May and 714 in September. Very few households, 34 in all, refused to take part; these were replaced by the next households. Individuals with a history of travelling or working in other regions were excluded from the study.

\section{Data collection}

Data were collected during the study period using 3 tools: a pre-structured and pre-tested questionnaire (population survey), environmental data form (meteorological and environmental survey) and entomological form (vector survey). Data was collected by trained personnel who were divided into 3 teams, each team composed of a trained social worker, public health officer, sanitary overseer, 2 laboratory technicians, entomology technician and medical doctor.

Thick and thin blood films were collected from all the individuals in the survey and stained with 5\% Giemsa stain for 20 minutes and 100 fields were examined at $10 \times$ 100 magnification by experienced microscopists for the presence of malaria parasites (stages and species). Parasite count was then calculated using the formula: No. of parasites $/ \mu \mathrm{L}=$ No. of asexual stages counted $\times 8000 \mathrm{WBC} /$ no. of WBC counted.

\section{Data analysis}

Data was analysed using SPSS, version 10.0 and Epi-Info, version 6.02. Proportions were compared using chi-squared and odds ratio was calculated where appropriate. The significance level ( $P$-value) was taken as $\leq 0.05$ at $95 \%$ CI. Multivariate analysis was also performed.

\section{Results}

Of the 8092 individuals surveyed during the study period, $62.6 \%$ were female. Ages ranged from 1 to 95 years (mean \pm standard deviation $=23.4 \pm 18.2$ ) and education level varied from no formal schooling to postgraduate.

Households with screened windows, using mosquito bednets or having both (as protective measures) were 5.0\% (95\% CI:

المجلة الصحية لشرق المتوسط، منظمة الصحة العالمية، المجلد التاسع، العدد ؟، ب... 
4.1-6.0), 10.9\% (95\% CI: 9.5-12.3 ) and $1.8 \%$ (95\% CI: $1.2-2.5$ ) respectively. Regarding access to health services, $98.7 \%$ (95\% CI: 98.1-99.1) of households were within $5 \mathrm{~km}$ of the nearest health facility. The private sector was preferred by $24.5 \%$ (95\% CI: 22.9-26.7\%) of households while $63.7 \%$ (95\% CI: 60.0-65.0) used the public sector and $11.8 \%$ (95\% CI: 9.912.7) were with nongovernmental organizations (Table 1). Only 3.8\% (95\% CI: 2.9-4.7) of households kept antimalarial drugs at home.

The incidence of malaria (history of getting/being treated for malaria) in the month prior to the survey was $25.5 \%$ (95\% CI: 24.5-26.5). However, the overall prevalence of malaria was very low as reflected by parasite rate $(0.21 \%, 95 \%$ CI: $0.12-$ $0.33)$, spleen rate $(0.17 \%$, $95 \%$ CI: $0.09-$ $0.29)$ and fever rate (febrile at time of visit) (0.97\%, 95\% CI: 0.77-1.20) (Table 2). The risk of getting malaria as measured by parasite rate and spleen rate was the same for age group 2-9 years and age group $\geq 10$ years (data not shown).

The risk of malaria transmission was greater in January; the parasite rate (0.35\%, 95\% CI: 0.17-0.66) and fever rate (2.10\%, 95\% CI: 1.57-2.63) were always higher in that month $(P$-value $<0.05)$. The rate of getting/being treated for malaria, on the other hand, was higher during May (28.97\%, 95\% CI: 26.96-30/98) (Figure $1)$. The upper temperature in Khartoum state ranged from $28.2{ }^{\circ} \mathrm{C}$ to $41.9{ }^{\circ} \mathrm{C}$ (mean \pm standard deviation $=37.2 \pm 4.4$ ) and the lower temperature ranged from $13.7^{\circ} \mathrm{C}$ to $27.8^{\circ} \mathrm{C}$ (mean \pm standard deviation $=23.2 \pm 4.5$ ). Khartoum experienced the highest temperatures in June (27.8$41.9^{\circ} \mathrm{C}$ ) and the lowest temperatures during January $\left(13.7-28.2^{\circ} \mathrm{C}\right)$. The relative humidity varied between $17.7 \%$ and $61.8 \%$ (mean \pm standard deviation $=33.6 \pm 13.6$ )
Table 1 Background characteristics of the study population, Khartoum urban area, Sudan, 2002

\begin{tabular}{|c|c|}
\hline Variable & Total \% (95\% Cl) \\
\hline $\begin{array}{l}\text { Households with } \\
\text { screened windows }\end{array}$ & $5.0(4.1-6.0)$ \\
\hline $\begin{array}{l}\text { Households using } \\
\text { bednets }\end{array}$ & $10.9(9.5-12.3)$ \\
\hline $\begin{array}{l}\text { Households with } \\
\text { screened windows } \\
\text { and using bednets }\end{array}$ & $1.8(1.2-2.5)$ \\
\hline $\begin{array}{l}\text { Households with } \\
\text { antimalarial drugs } \\
\text { at home }\end{array}$ & $3.8(2.9-4.7)$ \\
\hline $\begin{array}{l}\text { Households within } \\
5 \mathrm{~km} \text { of health } \\
\text { services }\end{array}$ & $98.7(98.1-99.1)$ \\
\hline $\begin{array}{l}\text { Sex } \\
\quad \text { Male } \\
\text { Female }\end{array}$ & $\begin{array}{l}37.4(36.4-38.4) \\
62.6(61.6-63.6)\end{array}$ \\
\hline $\begin{array}{l}\text { Age group (years) } \\
\quad<2 \\
2-9 \\
\geq 10\end{array}$ & $\begin{array}{r}4.2(03.8-04.6) \\
24.0(23.0-25.0) \\
71.8(70.8-72.8)\end{array}$ \\
\hline $\begin{array}{l}\text { Level of education } \\
\text { Not educated } \\
\text { Any level of } \\
\text { education }\end{array}$ & $21.9(21.0-22.8)$ \\
\hline $\begin{array}{l}\text { Preferred sector of } \\
\text { health services } \\
\text { Public } \\
\text { Private } \\
\text { Nongovernmental } \\
\text { organizations }\end{array}$ & $\begin{array}{l}63.7(60.0-65.0) \\
24.5(22.9-26.7)\end{array}$ \\
\hline
\end{tabular}

reaching the highest point in August and the lowest in May. Rains started to fall in 2002 during July and continued up to October, with $215.6 \mathrm{~mm}$.

With regard to the use of protective measures (screened windows, mosquito nets) there was a significant difference be- 
Table 2 Epidemiological indices obtained from the surveys, Khartoum urban area, Sudan, 2002

\begin{tabular}{lr}
\hline Variable & Total \% (95\% Cl) \\
\hline $\begin{array}{l}\text { Individuals getting/being } \\
\text { treated for malaria within }\end{array}$ & \\
$\quad$ the past month & $25.47(24.37-26.56)$ \\
Fever rate at time of visit & $0.97(0.77-1.20)$ \\
Parasite rate & $0.21(0.12-0.33)$ \\
Spleen rate & $0.17(0.09-0.29)$ \\
\hline
\end{tabular}

tween the 3 greater urban areas Khartoum, Bahry and Omdurman $(P$-value $<0.05)$ (Table 3). Greater Bahry had fewer mosquito bednets and fewer houses with antimalarial drugs at home. On the other hand, it had the highest parasite and spleen rates but the difference from the other areas was not statistically significant (Table 4). Of 17 households where parasites were detected, almost $60 \%$ were in Greater Bahry. In addition, $65 \%$ of cases of enlarged spleen and $50 \%$ of gametocytes were detected in Greater Bahry as well as $50 \%$ of the individuals with a history of getting/being treated for malaria.

Mapping of the area based on malaria prevalence and malaria incidence showed that Greater Bahry shoulders the highest burden. It is clearly demonstrated that there is correlation between the prevalence and incidence rates for malaria (Figure 2).

Indoor breeding was found in $2.8 \%$ (95\% CI: 2.1-3.6) of households. A total of 450 houses were surveyed for adult mos-

$\neg-$ Fever rate $\prec$ Parasite rate $-\checkmark$ Getting/being treated for malaria

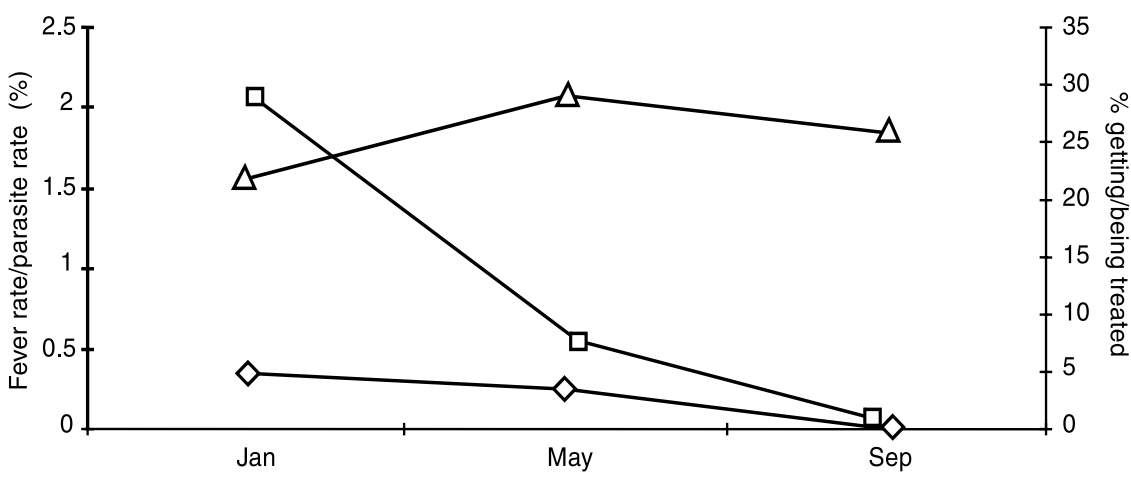

\begin{tabular}{lccc}
\hline Variable & January & May & September \\
\hline Average temperature range, ${ }^{\circ} \mathrm{C}$ & $13.7-28.2$ & $26.2-41.0$ & $27.1-39.2$ \\
Average relative humidity, \% & 28 & 17.7 & 54 \\
Rainfall, mm & 0 & 0 & 94.7 \\
\hline
\end{tabular}

Figure 1 Seasonal trend for fever rate, parasite rate and getting/being treated for malaria in the month prior to the survey, Khartoum urban area, 2002

المجلة الصحية لشرق المتوسط، منظمة الصحة العالمية، المجلد التاسع، العدد ؟، ب... 


\begin{tabular}{|c|c|c|c|c|c|}
\hline $\begin{array}{l}\text { Characteristics } \\
\text { of households }\end{array}$ & $\begin{array}{l}\text { Total no. } \\
\text { surveyed }\end{array}$ & $\begin{array}{c}\text { No. } \\
\text { positive }\end{array}$ & $\%$ & OR (95\% Cl) & $P$-value \\
\hline \multicolumn{6}{|c|}{ Screened windows } \\
\hline Khartoum ${ }^{\mathrm{a}}$ & 621 & 26 & 4.2 & - & \\
\hline Omdurman & 574 & 26 & 4.5 & $0.92(0.51-1.16)$ & 0.77 \\
\hline Bahry & 805 & 47 & 5.8 & $0.70(0.42-1.18)$ & 0.16 \\
\hline \multicolumn{6}{|l|}{ Using bednets } \\
\hline Khartoum ${ }^{\mathrm{a}}$ & 621 & 77 & 12.4 & - & \\
\hline Omdurman & 574 & 78 & 13.6 & $0.90(0.63-1.28)$ & 0.54 \\
\hline Bahry & 805 & 63 & 7.8 & $1.67(1.16-2.40)$ & $<0.01$ \\
\hline \multicolumn{6}{|c|}{$\begin{array}{l}\text { Screened windows } \\
\text { and using bednets }\end{array}$} \\
\hline Khartoum ${ }^{\mathrm{a}}$ & 621 & 15 & 2.4 & - & \\
\hline Omdurman & 574 & 7 & 1.2 & $2.00(0.76-5.46)$ & 0.12 \\
\hline Bahry & 805 & 14 & 1.7 & $1.40(0.63-3.09)$ & 0.36 \\
\hline \multicolumn{6}{|c|}{ Antimalarials at home } \\
\hline Khartoum a & 621 & 56 & 9.0 & - & \\
\hline Omdurman & 574 & 10 & 1.7 & $5.59(2.73-11.79)$ & $<0.01$ \\
\hline Bahry & 805 & 9 & 1.1 & $8.77(4.15-19.15)$ & $<0.01$ \\
\hline \multicolumn{6}{|c|}{ Health facility within $5 \mathrm{~km}$} \\
\hline Khartoum ${ }^{\mathrm{a}}$ & 621 & 603 & 97.1 & - & \\
\hline Omdurman & 574 & 552 & 96.2 & $1.34(0.68-2.63)$ & 0.36 \\
\hline Bahry & 805 & 802 & 99.6 & $0.13(0.03-0.45)$ & $<0.01$ \\
\hline
\end{tabular}

aReference category.

quitoes (150 in each survey). Anopheline mosquitoes were detected in $6(4.0 \%), 5$ (3.3\%) and $21(14.0 \%)$ houses in the January, May and September surveys respectively (overall rate was 7.1\%). These were sparsely distributed over the 3 greater urban areas throughout the survey months, with a range of $1-5$ mosquitoes in the majority of houses but in one house in Greater Bahry 27 mosquitoes were caught. According to morphological base [6] all anophline mosquitoes were identified as An. arabiensis. Dissection for sporozoites using saline and Giemsa stain revealed no sporozoites. Nuisance mosquitoes (Culex spp.) were detected in all 3 areas in considerable numbers.
Multivariate logistic regression analysis was performed to study the determinants of malaria incidence (getting malaria/being treated for malaria) during the month prior to the survey. The analysis revealed that significant risk factors for malaria were age $<5$ years, being female, region (Bahry and Omdurman are at a significantly higher risk compared to Khartoum) and season (higher risk during May and September compared to January) (Table 5).

\section{Discussion}

Malaria in the Khartoum area is considered unstable, with the characteristics of urban 
Table 4 Variation in indicators of malaria prevalence in $\mathbf{3}$ greater urban areas of Khartoum state, 2002

\begin{tabular}{|c|c|c|c|c|c|}
\hline Characteristics & $\begin{array}{c}\text { Total } \\
\text { surveyed }\end{array}$ & No. & $\%$ & OR $(95 \% \mathrm{Cl})$ & $P$-value \\
\hline \multicolumn{6}{|l|}{$\begin{array}{l}\text { Individuals getting/ } \\
\text { being treated for } \\
\text { malaria }\end{array}$} \\
\hline Khartoum ${ }^{\mathrm{a}}$ & 2649 & 510 & 19.3 & - & \\
\hline Omdurman & 2201 & 548 & 24.8 & $1.39(1.21-1.60)$ & $<0.01$ \\
\hline Bahry & 3242 & 1003 & 30.9 & $1.88(1.66-2.13)$ & $<0.01$ \\
\hline \multicolumn{6}{|l|}{$\begin{array}{l}\text { Individuals febrile } \\
\text { at time of visit }\end{array}$} \\
\hline Khartoum ${ }^{\mathrm{a}}$ & 2649 & 4 & 0.2 & - & \\
\hline Omdurman & 2201 & 51 & 2.3 & $15.69(5.43-51.08)$ & $<0.01$ \\
\hline Bahry & 3242 & 24 & 0.7 & $4.90(1.62-16.7)$ & $<0.01$ \\
\hline \multicolumn{6}{|l|}{ Parasite rate } \\
\hline Khartoum ${ }^{\mathrm{a}}$ & 2649 & 3 & 0.1 & - & \\
\hline Omdurman & 2201 & 4 & 0.2 & $1.61(0.31-9.01)$ & 0.53 \\
\hline Bahry & 3242 & 10 & 0.3 & $2.73(0.70-12.48)$ & 0.11 \\
\hline \multicolumn{6}{|l|}{ Spleen rate } \\
\hline Khartoum a & 2649 & 3 & 0.1 & - & \\
\hline Omdurman & 2201 & 2 & 0.1 & $0.80(0.09-5.86)$ & 0.80 \\
\hline Bahry & 3242 & 9 & 0.3 & $2.46(0.61-11.42)$ & 0.16 \\
\hline
\end{tabular}

${ }^{a}$ Reference category.

malaria. Dr Balfour, who conducted the first organized malaria control programme in the area, succeeded with simple measures (larval control with retained oil) to eradicate malaria from Khartoum in 1904 [7]. Malaria incidence then remained low up to the 1970s then it increased again. This was attributed to a number of factors, including unplanned urbanization, influx of internally displaced people and refugees (mainly from hyperendemic areas) and deterioration and/or discontinuation of malaria control activities.

Surveys conducted for the state Malaria Control Programme during 1995-2002 showed prevalence rates ranging from $0.8 \%$ to $5.1 \%$. The highest prevalence was detected during 1998-2000. The low prevalence detected throughout our study, as reflected by parasite rate $(0.21 \%)$, spleen rate $(0.27)$ and fever rate $(0.97 \%)$ is consistent with the results reported for the control programme in November 2002 (prevalence rate $=0.07 \%)$. The highest prevalence, detected during the cold season survey, also parallels the previous survey results which showed higher prevalence during the March survey (cold season) compared to the September survey (rainy season) (Khartoum state Malaria Control Programme, unpublished data, 2002). There has been to some extent a regular control programme in Khartoum since 1994 and additional measures were carried out during 2002 after the launch of the Khartoum Malaria Free Initiative in May 2002. The project was the product of a partnership between the World Health Or-

المجلة الصحية لشرق المتوسط، منظمة الصحة العالمية، المجلد التاسع، العدد ع، ب... 


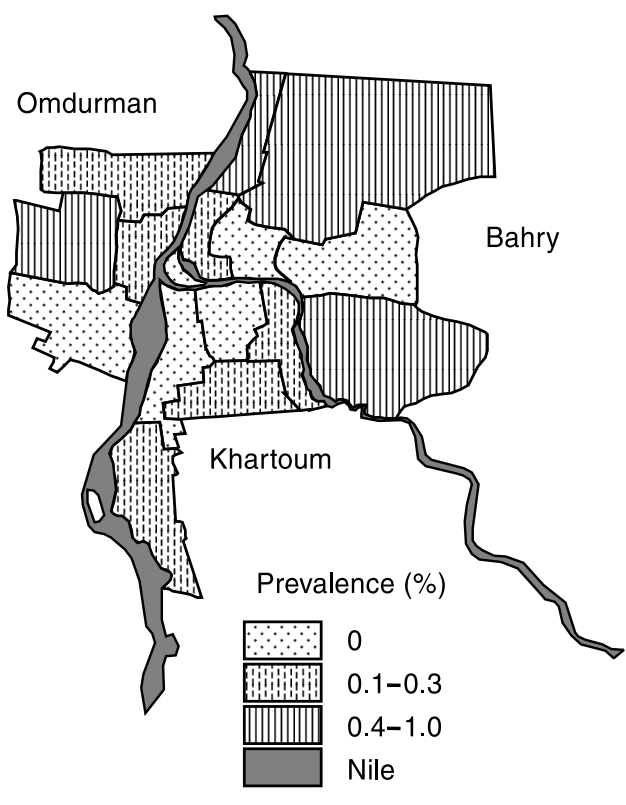

A

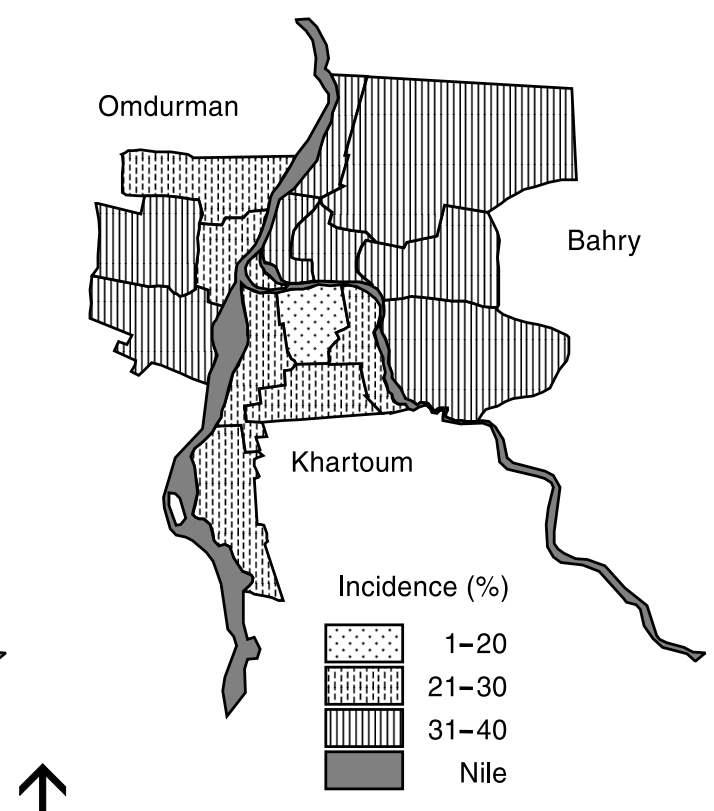

North
B

Figure 2 Malaria prevalence rate (A) and incidence rate (B) for 3 urban zones, Khartoum urban area, 2002 (subdivision of each greater area reflected)

ganization, Sudan Federal Ministry of Health and Khartoum State Government. The results obtained so far indicate that Khartoum is hypoendemic and no longer a mesoendemic zone as assigned by earlier surveys (W. Wernsdorfer, unpublished data, 1960). This was confirmed by the prevalence rate among various age groups, which showed no significant difference between prevalence of malaria in all ages and in those 2-9 years. In spite of this, the history of treatment for malaria in the month preceding the survey showed a very high incidence (average 25.5\%). More cases were noticed in a similar urban area (bordered by an irrigated zone) in Sudan where
$>40 \%$ received at least one course of antimalarial drugs during the 4-week period [8]. Low sensitivity and specificity detected in slides examined at health centres as well as at hospital level may explain this. In a study conducted in 1995-96, sensitivity varied between $50 \%$ and $75 \%$ and specificity between $52 \%$ and $95 \%$ [9]. Later surveys conducted by the control programme revealed similar results (Khartoum State Malaria Control Programme, unpublished data, 2002). When read against the very low parasite rate $(0.21 \%)$, the recorded frequency of getting/being treated for malaria during the month prior to the survey

المجلة الصحية لشرق المتوسط، منظمة الصحة العالمية، المجلد التاسع، العدد ع، ب... 


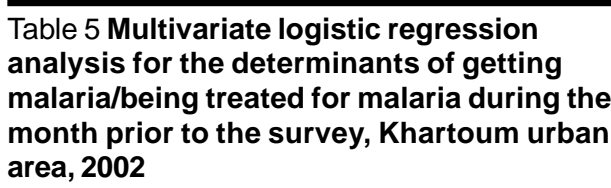

\begin{tabular}{|c|c|c|}
\hline Determinant & Adjusted OR & $95 \% \mathrm{Cl}$ \\
\hline \multicolumn{3}{|l|}{ Age (years) } \\
\hline$\leq 5^{a}$ & 1 & \\
\hline$>5$ & 0.5 & $0.44-0.58^{b}$ \\
\hline \multicolumn{3}{|l|}{ Sex } \\
\hline Male $^{\mathrm{a}}$ & 1 & \\
\hline Female & 1.14 & $1.02-1.27^{b}$ \\
\hline \multicolumn{3}{|c|}{ Distance to health facility } \\
\hline$\leq 5 \mathrm{~km}^{\mathrm{a}}$ & 1 & \\
\hline$>5 \mathrm{~km}$ & 0.99 & $0.95-1.03$ \\
\hline \multicolumn{3}{|c|}{$\begin{array}{l}\text { Presence of screened } \\
\quad \text { windows }\end{array}$} \\
\hline$Y_{e s}^{a}$ & 1 & \\
\hline No & 1.01 & $0.79-1.29$ \\
\hline \multicolumn{3}{|c|}{ Presence of bednets } \\
\hline$Y_{e s}^{a}$ & 1 & \\
\hline No & 1.03 & $0.87-1.23$ \\
\hline \multicolumn{3}{|c|}{ Indoor breeding } \\
\hline$Y_{e s}^{a}$ & 1 & \\
\hline No & 0.93 & $0.67-1.28$ \\
\hline \multicolumn{3}{|l|}{ Region } \\
\hline Khartoum ${ }^{\mathrm{a}}$ & 1 & \\
\hline Omdurman & 1.38 & $1.20-1.59^{b}$ \\
\hline Bahry & 1.86 & $1.63-2.12^{\mathrm{b}}$ \\
\hline \multicolumn{3}{|l|}{ Season } \\
\hline Januarya & 1 & \\
\hline May & 1.27 & $1.12-1.45^{\mathrm{b}}$ \\
\hline September & 1.31 & $1.15-1.50^{\mathrm{b}}$ \\
\hline
\end{tabular}

${ }^{a}$ Reference category.

${ }^{b}$ Odds ratios significant.

(25.5\%) expresses an obvious tendency to overdiagnose any febrile case as malaria.

The indoor and outdoor breeding sites detected during this study reflected the typical features of urban areas: multiple, small, man-made breeding sites mainly due to broken water pipes and tanks on construc- tion sites in addition to some irrigated areas along the Nile banks and in small agricultural schemes. In such situations, in low or unstable malaria transmission, the recommendation of conducting classic vectorcontrol methods in Africa for the elimination of malaria in urban areas [10] may be considered. However, the relatively small number of anopheline mosquitoes collected during the survey, with zero sporozoite rates (although not enough mosquitoes were collected to draw up firm conclusions) may explain the low prevalence. The considerable number of culicine mosquitoes detected in almost every house surveyed, on the other hand, raised suspicion of malaria in individuals as well as prescribers, and thus many febrile patients were misdiagnosed as having malaria. This also raises suspicion about the co-existence of other diseases transmitted by this vector. Although small sized breeding sites were detected everywhere, anopheline mosquitoes, with very few exceptions, were found only in zones adjacent to agricultural areas. No anopheline mosquitoes were detected in Greater Omdurman as this area has very limited irrigated areas. This agreed with other studies in which environmental factors such as presence of water for irrigation were found to be important determinants of anopheline mosquito breeding [11,12].

The use of protective measures seems to be very limited, only a small minority of households had bednets or screened windows. The rates are similar to other urban areas, where the use of bednets varies between $4.9 \%$ and $26.0 \%[13,14]$. None of the individuals with positive test results for malaria was using protective measures such as insecticide-treated bednets.

In conclusion, the overall results showed that people in Greater Bahry and Greater Omdurman urban areas were at higher risk of getting malaria. Both areas

المجلة الصحية لشرق المتوسط، منظمة الصحة العالمية، المجلد التاسع، العدد ع، بr. 
showed higher parasite rate, higher spleen rate or presence of gametocytes. We recommend that Khartoum Malaria Free Initiative continue its efforts using integrated vector control with the emphasis on environmental measures. Particular attention should be given to coordination with the water corporation as broken pipes are the main source of breeding sites.

\section{Acknowledgements}

This investigation received technical and financial support from the joint WHO Eastern Mediterranean Region (EMRO),
Division of Communicable Diseases (DCD) and the WHO Special Programme for Research and Training in Tropical Diseases (TDR): The EMRO/TDR Small Grants Scheme for Operational Research in Tropical and Communicable Diseases.

Many thanks to the programme coordinators. In addition, we would like to thank Dr Mohamed Omer of Khartoum State Ministry of Health, who helped greatly in the construction of maps shown here. The team would also like to thank the people in Khartoum urban area for their acceptance and welcome.

\section{References}

1. Roll Back Malaria in the WHO Eastern Mediterranean Region. Cairo, World Health Organization Regional Office for the Eastern Mediterranean, 2002 (WHO$\mathrm{EM} / \mathrm{MAL} / 273 / \mathrm{E} / \mathrm{G} / 12.01 / 3000)$.

2. El Sayed BB et al. A study of the urban malaria transmission problem in Khartoum. Acta tropica, 2000, 75(2): 163-71.

3. Carter R, Mendis KN, Roberts D. Spatial targeting of intervention against malaria. Bulletin of the World Health Organization, 2000, 78(12):1401-11.

4. Sabatinelli $G$ et al. Prevalence du paludisme á Ouagadougou et dans le milieu rural limitrophe en pèriode de transmission maximale [Prevalence of malaria in Ouagadougou and the surrounding rural environment during the period of maximal transmission]. Parasitologia, 1986, 28:17-31.

5. Central Bureau of Statistics and United Nations Population Fund. CBS Year Book (Population data sheet for Sudan by states). Khartoum, Sudan, 2000.
6. Gillies MT, Coetzee M. A supplement to the Anophelinae of Africa south of the Sahara. Johannesburg, South Africa, Publications of the South African Institute for Medical Research, No. 55, 1987.

7. Balfour A. First report of the Wellcome Tropical Research Laboratories at the Gordon Memorial College, Khartoum. Khartoum, Department of Education, Sudan Government, 1904.

8. Yousif MA, Adeel AA. Antimalarial prescribing patterns in Gezira State: precept and practices. Eastern Mediterranean health journal, 2000, 6(5-6):939-47.

9. Ibrahim SM. Decisive assessment of diagnostic staining methods of malaria in eight public and private laboratories, Khartoum area. In: Operational research in tropical diseases, final report summaries 1992-2000. Cairo, World Health Organization Regional Office for the Eastern Mediterranean, 2003 (WHOEM/TDR/004/E/G). 
10. Trape JF et al. Combating malaria in Africa. Trends in parasitology, 2002, 18 (5):224-30.

11. Clarke SE et al. Risk of malaria attack in Gambian children is greater away from malaria vector breeding sites. Transactions of the Royal Society of Tropical Medicine and Hygiene, 2002, 96(5): 499-506.

12. Guthman JP et al. Environmental factors as determinants of malaria risk: A descriptive study on the northern cost of Peru. Tropical medicine and international health, 2002, 7(6):518-25.
13. Dosson-Yavo J, Amalaman K, Carnevale P. Itineraires et pratiques thérapeutiques antipaludiques chez les citadins de Bouake, Côte d'Ivoire [Antimalarial guidelines and therapy practices of the population of Bouake, Ivory Coast]. La medicina tropical, 2001, 61(6):495-9.

14. Nuwaha F. People perception of malaria in Mbarara, Uganda. Tropical medicine and international health, 2002, 7(5): 462-70.

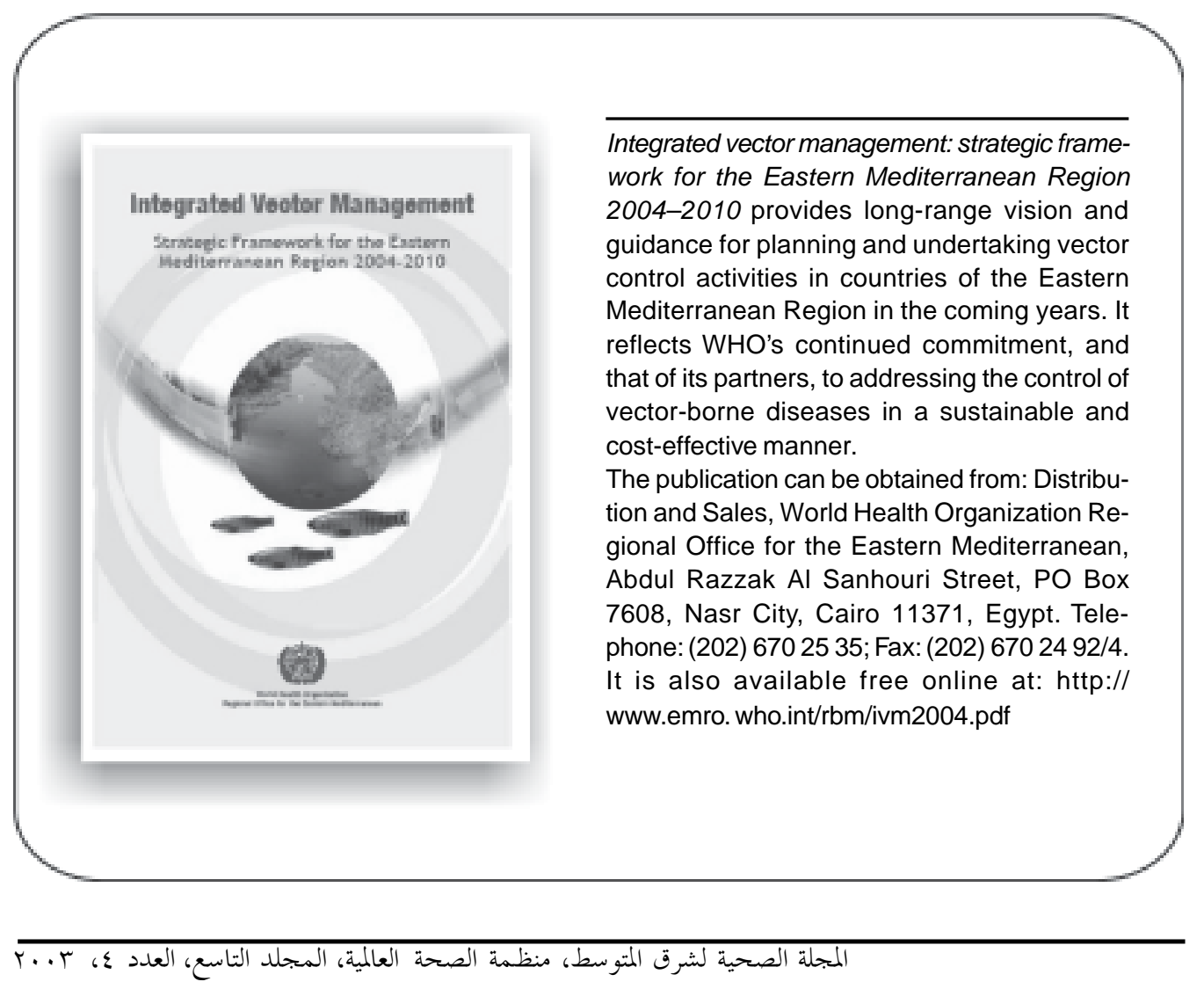

